\title{
The Effect of Entrepreneurial Marketing on Managing Resources and Its Impact on Innovation Performance
}

\author{
Triyono Arief Wahyudi ${ }^{1 *}$ \\ ${ }^{1}$ Kalbis Institute \\ Email: triyono.wahyudi@kalbis.ac.id
}

\begin{abstract}
Globalization affects businesses all over the world, including Indonesia. It results on an increased global competition. Hence, the Indonesian company must compete with other global companies, which can also be outside the industry. Therefore, managers should have the valuable orientation in managing their resources toachieve the competitive advantage through creating innovation performance. This research offers entrepreneurial marketing as these valuable orientations. The objective of this study was to analyze the effect of entrepreneurial marketing on managing resources and to analyze the influence of managing resources on innovation performance. Quantitative method was employed along with the conceptual model which consisted of three constructs. These were entrepreneurial marketing, managing resources and innovation performance.
\end{abstract}

There are two hypotheses. The unit of analysis were the managerial level of manufacture companies. The data is collected through distributed questionnaires. The collected questionnaire is 91 out of 215 distributed questionnaires. The data set is analyzed by using the SPSS (Statistical Package for the Social Sciences) for reliability test, validity test, normality test and hypothesis tests. The findings of the study resulted on the acceptance of all hypotheses. The contribution on theoretical manner is the empirical evident of the effect of entrepreneurial marketing on managing resources and the effect of managing resources on innovation performance. The managerial implication of this research is the entrepreneur could creatively explore entrepreneurial marketing's elements which are proactiveness, opportunity focus, calculated risk taking, innovativeness, customer intensity, resource leveraging and value creation to manage resources for achieving the best innovation performance.

Keywords: Entrepreneurial Marketing; Value Creation; Innovativeness; Managing Resources, Innovation Performance.

\section{Introduction}

The fourth industrial revolution has come at a recent time. It is a continuation of the third ones which is the digital revolution since the 1960s. It affects the change on any economic and business environment. Characteristics of technology, products and customers have changed faster than before. There are some emerging industries like application industry, e-commerce industry and e-products or e-service industry. Some industries are in the mature-decline phase on the industry life cycle. Those industries are printing industry, non-electronic publishing industry (books, newspapers, magazines, etc.), non-electronic music industry, game console 
industry and so on. While many multi-national companies which have had long history of existence closed their manufacture operation down in Indonesia such as Sony, Toshiba, Sharp, Ford etc. Some companies in the industries drop their business by decreasing number of their employees, working hours and/or closing their branches down. The others could survive in running their business. These companies can do innovation to achieve the best market position through competitive advantage. Innovation performance could be affected by the way of companies to manage their resources.

To achieve competitive advantage on market position, companies must be adaptable, flexible and responsive on the business environmental changes. The changes have happened on many industrial sectors. These companies have managed their resources proportionally to strengthen their market position in achieving the best financial performance. Therefore, understanding the market needs and wants would affect the way of companies to manage their resources. Morris, Schindehutte, and LaForge (2002) described a concept of entrepreneurial marketing (EM) which is the intersection between entrepreneurship and marketing. It contains proactiveness, opportunity focus, calculated risk taking, innovativeness, customer intensity, resources leveraging and value creation.

By using entrepreneurial marketing, the companies manage their resources in doing innovation process to achieve competitive advantage on the competition arena. This research objective was to analyze the effect of entrepreneurial marketing on managing resources and to analyze the influence of managing resources on innovation performance. This research has structure which is started by reviewing some literature such as resource-advantage theory of competition, resource-based view (RBV), entrepreneurial marketing and innovation in developing conceptual model and hypothesis. It followed by constructing research methodology which involves measurement, sample and data collection. Analysis and result of the research consist some tests such as validity, reliability, normality and hypothesis test. The last part is discussion and conclusion of the research finding.

\section{Literature Review}

This research used several theories and concepts to describe the foundation of research conceptual model. These are resource-advantage theory of competition, resource-based view (RBV), entrepreneurial marketing and innovation.

\subsection{Resource-Advantage Theory of Competition and Resource-based View (RBV)}

Resource-advantage theory of competition Hunt and Morgan (1997) is a general theory of competition which explain the usage of resources on competition process. Resources can be the tangible and intangible things in a company which is able to produce innovatively a product and/or a service that has value for the customers. Resources consist human resources, financial resources, company reputation, business network, physical resources such as building, machineries and raw materials, capabilities and skill.

Figure 1 describes the resource-advantage theory of competition. Companies could have superior financial performance, whenever they build competitive advantage on market position through its managed resources properly. The importance of resource-based view (RBV) (see Wernerfelt, 1984; Rumelt, 1991; Barney, 1991) on the market positions is the company could manage its 


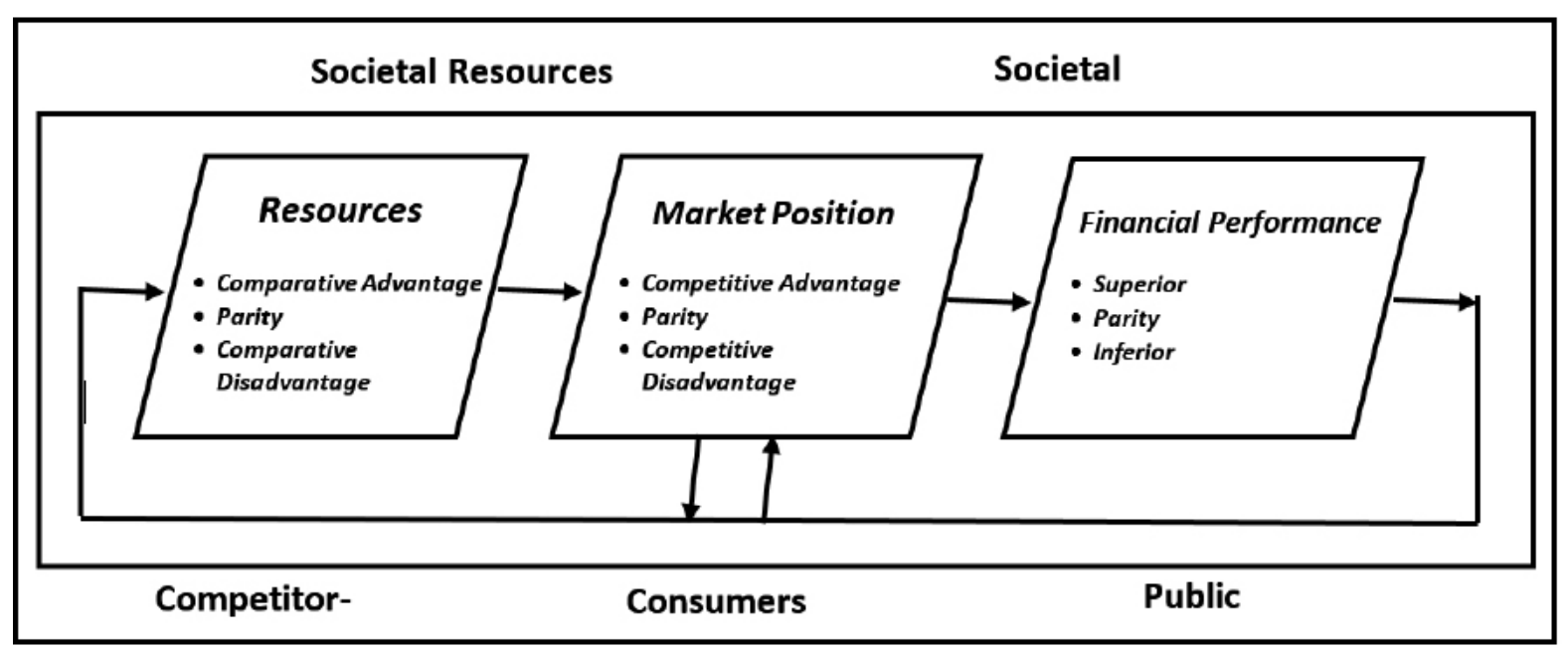

Figure 1. Resource-advantage theory of competition (Hunt and Morgan, 1997)

innovative combination of resources and capabilities to achieve competitive advantage. By having competitive advantage, a company could perform better than competitors.

To sustain the competitive advantage, it must manage resources in a way to be valuable, rare and inimitability (Peteraf, 1993). A company uses resources to create customer value that is rare and costly to imitate. In this way, it improves market position relative to competitors. Barney (1991) propose firm resources include all assets, capabilities, organizational processes, firm attributes, information, knowledge, etc. controlled by a firm that enable the firm to conceive of and implement strategies that improve its efficiency and effectiveness.

While Kay (1999) explain, resources are inputs into a firm's production process, such as capital, equipment, the skills of individual employees, patents, finance, and talented managers. Resources are either tangible or intangible in nature.

Barney, Ketchen Jr and Wright (2011) explain that resource-based theory (RBT) is important relationships among organizational phenomena need to be mindful of the need to further innovate and ensure that RBT achieves revitalization and avoids decline. Klingebiela and Rammerb (2011) suggest limited resource commitments through selectiveness contains breadth's disadvantages, a combination that provides flexibility in resource allocation.

\subsection{Innovation}

Drucker (1983) defines innovation as simply the application of knowledge to produce new knowledge. While Kim, and Park (2010) propose innovation as the role of continuous improvement. Gassmann, Enkel and Chesbrough (2010) describes innovation as an organization ability to respond the change in its internal or external environment or as a preemptive move taken to influence that environment. Mention (2011) explains the success in innovation results from naturalizing an innovation's novelty and managing expectations.

Gronum, Verreynne, and Kastelle, T. (2012) describe a critical role of innovation to achieve superior performance. Gronum et al. (2012) suggest that innovation is important for a company to gain the learning process. Innovation leads a company perform financially better than 
competitors through implementing the concept of valuable, rare, inimitable and differentiated products (Zahra and George, 2002). Hung and Chou (2013) explain innovative capability significantly influence a company to achieve strategic competitiveness. Barney (1991) proposes that companies can achieve a competitive advantage through its unique resources compare to the competitors. Innovation is described as product or process, technical or administrative, and radical or incremental.

Salter, Cricuolo and Ter Wal (2014) explain company manage its resources through process innovation improving efficiency. Salter, Cricuolo and Ter Wal (2014) also propose process management practices to optimize organizational processes in creating the opportunities to achieve efficiency. However, Kim and Park (2010) conclude that company's business process in managing its resources had a significant positive relationship with innovation performance. Innovation performance are tangible, such as new product, product improvement, process improvement, new business model, business model improvement, revenue increase, profitability increase and cost reduction.

\subsection{Entrepreneurial Marketing}

Entrepreneurial marketing is the important construct in managing company resources for creating innovation performance to achieve a competitive advantage. It is an interface between two different management domains. Both management domain are entrepreneurship and marketing. Drucker (1985) developed these earlier ideas by defining an entrepreneur as someone who searches for change, but responds to it in an innovative way, exploiting it as an opportunity.

Zahra, Filatotchev, and Wright (2009) describe the entrepreneurial characteristics, such as opportunistic, innovative, proactive and restless. Entrepreneurial marketing (Morris, et al., 2002; Bjerke and Hultman, 2002) is defined as the proactive identification and exploitation of opportunities for acquiring and retaining profitable customers through innovative approaches to risk management, resource leveraging and value creation. While Becherer, Haynes and Fletcher (2006) describe entrepreneurial marketing is the marketing processes of companies in chasing opportunities in uncertain market and under limited resource conditions.

Hills, Hultman, and Miles (2008) propose entrepreneurial marketing (EM) is: “...a spirit, an orientation as well as a process of passionately pursuing opportunities and launching and growing ventures that create perceived customer value through relationships by employing innovativeness, creativity, selling, market immersion, networking and flexibility". Becherer, Helms, and McDonald (2012) explain the seven dimensions of entrepreneurial marketing. These are proactiveness, opportunity focus, calculated risk taking, innovativeness, customer intensity, resource leveraging and value creation.

\subsection{Conceptual Model of the Research}

Conceptual Model on this research consist three constructs. These are entrepreneurial marketing as independent variable, innovation performance as dependent variable and managing resources as mediating variable.

Entrepreneurial marketing as an independent variable is defined as Proactive identification and exploitation of opportunities for acquiring and retaining profitable customers through 


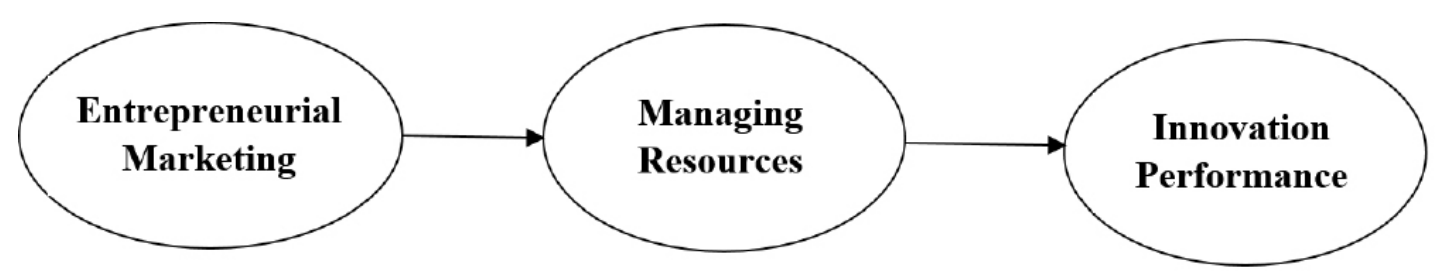

Figure 2. Conceptual model of the research

innovative approaches to risk management, resource leveraging and value creation (Morris, et al., 2002). In this research, indicators of entrepreneurial marketing are proactiveness, opportunity focus, risk taking, customer intensity, innovativeness, resources leveraging and value creation (Becherer et al., 2012).

Managing resources as a mediating variable. Resources are the company's assets either the tangible and intangible things which is used to produce innovatively a product and/or a service that has value for its customers. Klingebiela and Rammerb (2011) suggest a policy of allocating resources to a broader range of innovation projects increases sales of new products, especially if these are truly novel, i.e. new to the market. Managing resources consist managing human resources, financial resources, company reputation, business network, physical resources such as building, machineries and raw materials; capabilities and skill.

Miller, Wright, and Le Breton-Miller (2015) explored how preferences, together with theirimpact on resources and the innovation demands of their markets, shape the approach to innovation. Innovation performance is the process outcome of managing company resources to achieve its competitive advantage. These are tangible, such as new product, product improvement, process improvement, new business model, business model improvement, revenue increase, profitability increase and cost reduction.

Previous research conducted by Hacioglua et al. (2012) explain the finding about elements of entrepreneurial marketing that proactiveness, innovativeness, customer intensity, resource leveraging dimensions of entrepreneurial marketing are positively related with innovative performance.

\subsection{Research Hypothesis}

Many companies face the challenges in recent global competition. Entrepreneurial marketing proposes the marketing processes of companies in chasing opportunities in uncertain market and under limited resource conditions (Becherer et al., 2006). The successful company compete using the proactive identification and exploitation of opportunities for acquiring and retaining profitable customers through innovative approaches to risk management, resource leveraging and value creation (Morris et al., 2002).

Therefore, author propose the first hypothesis that:

H1: Entrepreneurial marketing has a positive and significant influence on Managing resources

Company manage its resources through process innovation for improving efficiency (Salter et al., 2014). Company's business process in managing its resources had a significant positive relationship with innovation performance (Kim and Park, 2010). 
Innovation leads a company perform financially better than competitors through implementing the concept of valuable, rare, inimitable and differentiated products (Zahra and George, 2002). Barney (1991) proposes that companies can achieve a competitive advantage through its unique resources compare to the competitors. As such, author propose that company manage its valuable resources to achieve competitive advantage in strengthening its market position through innovation performance.

Therefore, author propose the second hypothesis that:

$\mathrm{H} 2$ : Managing resources have a positive and significant influence on innovation performance

\section{Research Methodology}

\section{1. $\quad$ Measure}

In this research, the author aimed to test the influence of entrepreneurial marketing on managing resources and its impact on innovation performance. A field survey using questionnaires was conducted to collect data.

This research developed the constructs by using measurement scales which is adopted from prior research. All constructs are measured using five-point Likert scales ranging from $1=$ strongly disagree to $5=$ strongly agree. Items for measuring entrepreneurial marketing are namely proactiveness, opportunity focus, risk taking, customer intensity, innovativeness, resources leveraging and value creation. To measure a company's managing resources, the scale has managing human resources, financial resources, company reputation, business network, physical resources such as building, machineries and raw materials; capabilities and skill. While company's innovative performance is measured by new product, product improvement, process improvement, new business model, business model improvement, revenue increase, profitability increase and cost reduction.

\section{2. $\quad$ Sample and Data Collection}

The hypothesized relationships were tested with the data collected through structured questionnaires distributed to managers of companies located in Jakarta, Tangerang, Bekasi, Karawang, Depok, and Bogor. Data were collected through face-to-face interviews and email with managerial level of the manufacture companies. Sample size of this research is 91.

\section{Analysis and Results}

\subsection{Validity, Reliability}

All constructs, entrepreneurial marketing, managing resources and innovation performance have tested validity and reliability. By using SPSS (Statistical Package for the Social Sciences), the reliability test is conducted

Table 1 shows that the reliability test which Cronbach's alpha of each variable is more than 0.6. and the validity test which is each item of loading factor is more than 0.2061 for $\mathrm{N}=91$ and error 5\%. Hence, all the variables are reliable and the items are valid. 
Table 1. Reliability and Validity Test

\begin{tabular}{|c|c|c|c|c|}
\hline items & mean & EM & MR & IP \\
\hline EM1: Proactiveness, & 2.97 & 0.732 & & \\
\hline EM2: Opportunity focus, & 3.12 & 0.477 & & \\
\hline EM3: Calculated risk taking, & 3.09 & 0.665 & & \\
\hline EM4: Innovativeness, & 3.10 & 0.580 & & \\
\hline EM5: Customer intensity, & 3.13 & 0.753 & & \\
\hline EM6: Resource leveraging & 3.04 & 0.756 & & \\
\hline EM7: value creation & 3.11 & 0.742 & & \\
\hline MR1: Human resources & 3.14 & & 0.592 & \\
\hline MR2: Financial resources & 3.15 & & 0.579 & \\
\hline MR3: Company reputation & 3.11 & & 0.646 & \\
\hline MR4: Business network & 3.03 & & 0.675 & \\
\hline MR5: Building & 3.08 & & 0.654 & \\
\hline MR6: Machineries & 3.16 & & 0.725 & \\
\hline MR7: Raw materials & 3.08 & & 0.516 & \\
\hline MR8: Capabilities and skill & 3.13 & & 0.416 & \\
\hline IP1: New product & 3.18 & & & 0.646 \\
\hline IP2: Product improvement & 3.11 & & & 0.576 \\
\hline IP3: Process improvement & 3.12 & & & 0.606 \\
\hline IP4: New business model & 3.04 & & & 0.685 \\
\hline IP5: Business model improvement, & 3.04 & & & 0.543 \\
\hline IP6: Revenue increase & 3.11 & & & 0.501 \\
\hline IP7: Profitability increase & 3.09 & & & 0.659 \\
\hline IP8: Cost reduction & 3.10 & & & 0.410 \\
\hline $\mathrm{N}$ of Items & & 7 & 8 & 8 \\
\hline Cronbach's Alpha & & 0.883 & 0.858 & 0.844 \\
\hline
\end{tabular}

\subsection{Normality Test}

The data set which is collected on this research, is calculated by normality test using onesample Kolmogorov-Smirnov test. Table 2 provides the result of normality test which data set is normally distributed.

\subsection{Hypothesis Test}

In testing research hypothesis, the conceptual model is divided into two sub conceptual model. Figure 3 describes the first sub model is to test the first hypothesis. Entrepreneurial marketing is the independent variable. While managing resources is the dependent variable.

Table 3 consists the output table that provides the $\mathrm{R}$ and $\mathrm{R} 2$ values. The $\mathrm{R}$ value represents the simple correlation and is 0.721 (the "R" Column), which indicates a high degree of correlation. The $\mathrm{R} 2$ value (the "R Square" column) is 0.520 which indicates how much of the total variation 
Table 2. One-sample Kolmogorov-Smirnov Test

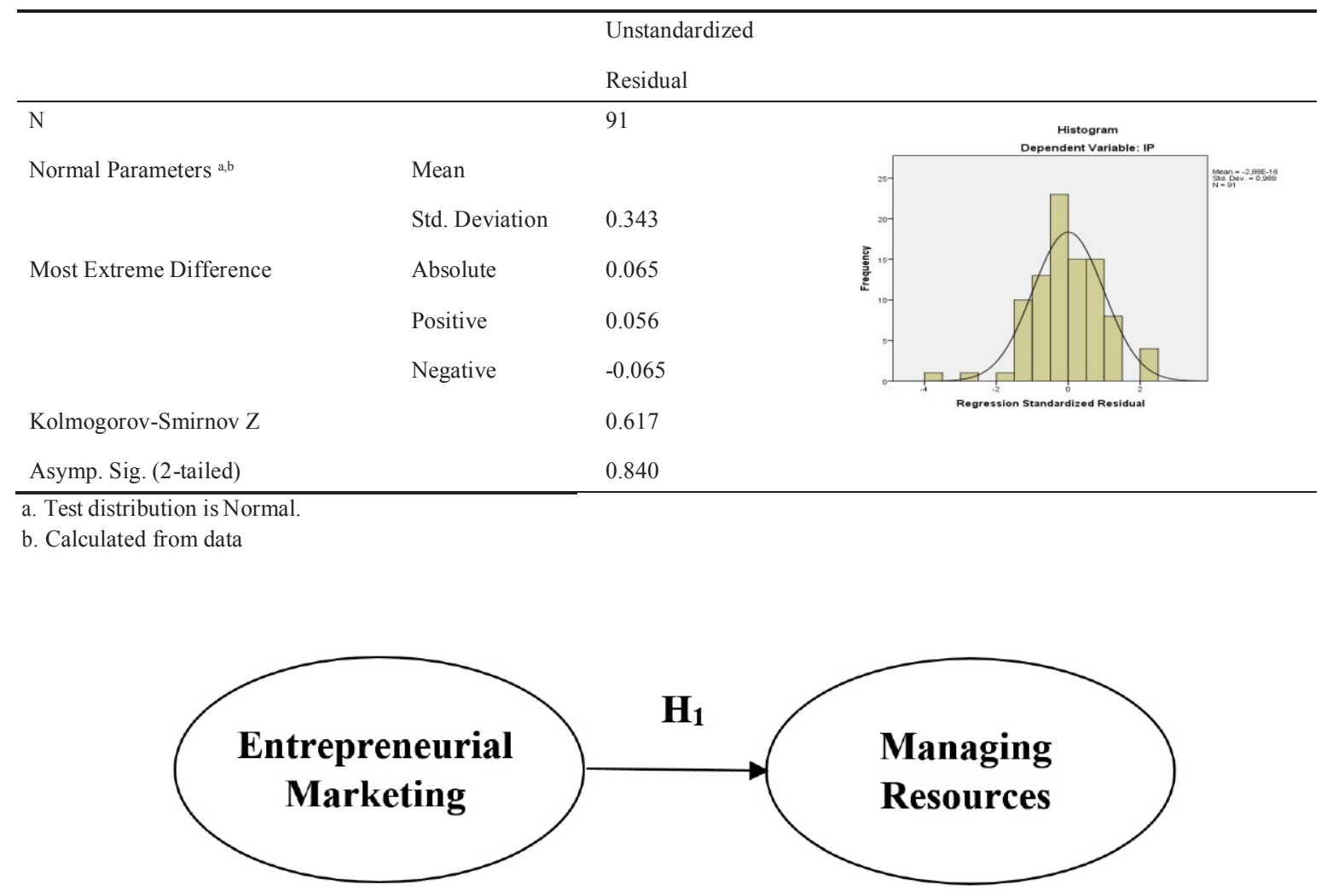

Figure 3. The first sub-model

Table 3. Coefficient of determination for the first sub-model

\begin{tabular}{|c|c|c|c|c|}
\hline $\mathrm{R}$ & R Square & Adjusted R Square & Std. Error of the Estimate & b. Dependent Variable: MR \\
\hline $0.721^{\mathrm{a}}$ & 0.520 & 0.515 & 0.4137 & \\
\hline
\end{tabular}

Table 4. Regression analysis for the first sub-model

\begin{tabular}{|c|c|c|c|c|c|c|}
\hline \multicolumn{2}{|c|}{ Model } & \multirow{2}{*}{$\begin{array}{c}\text { Unstandardized } \\
\text { B }\end{array}$} & \multirow{2}{*}{$\begin{array}{l}\text { Coefficients } \\
\text { Std. Error } \\
\end{array}$} & \multirow{2}{*}{$\begin{array}{c}\begin{array}{c}\text { Standardized } \\
\text { Coefficients }\end{array} \\
\text { Beta } \\
\end{array}$} & \multirow{2}{*}{$\mathrm{t}$} & \multirow{2}{*}{ Sig. } \\
\hline & & & & & & \\
\hline 1 & Constant & 1.054 & 0.214 & & 4.926 & 0.000 \\
\hline & EM & 0.668 & 0.068 & 0.721 & 9.821 & 0.000 \\
\hline
\end{tabular}

a. Dependent Variable: Managing Resources (MR)

in the dependent variable, managing resources (MR), can be explained by the independent variable, entrepreneurial marketing (EM). In this case, $52.0 \%$ can be explained.

Table 4 shows that the Coefficients table provides with the necessary information to predict managing resources (MR) from entrepreneurial marketing (EM). Furthermore, the values in the "B" column under the "Unstandardized Coefficients" column, as shown below:

The "tt" column shows the calculated t value is 9,821 which is more than critical t value 1.981, 


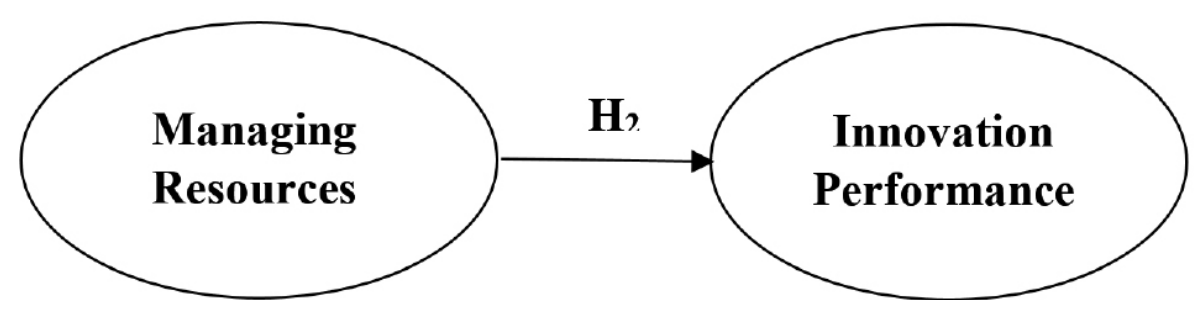

Figure 4. The second sub-Model

while the "Sig." column is 0.000 which is $<0.05$. These indicates entrepreneurial marketing (EM) influence significantly on managing resources (MR). Therefore, the first hypothesis $\left(\mathbf{H}_{1}\right)$ is supported by collected data.

The regression equation is:

$$
\text { Managing resources }=1,054+0.668 \text { (Entrepreneurial Marketing) }
$$

The second sub model is to test the second hypothesis as shown on table 4. Managing resources is the independent variable. While innovation performance is the dependent variable.

Table 5 describes the output table provides the $\mathrm{R}$ and $\mathrm{R} 2$ values. The $\mathrm{R}$ value represents the simple correlation and is 0.716 (the " $\mathrm{R}$ " Column), which indicates a high degree of correlation. The R2 value (the "R Square" column) is 0.513 which indicates how much of the total variation in the dependent variable, managing resources (MR), can be explained by the independent variable, innovation performance (IP). In this case, $51.3 \%$ can be explained.

Table 6 describes the Coefficients table provides with the necessary information to predict innovation performance (IP) from managing resources (MR). Furthermore, the values in the "B" column under the "Unstandardized Coefficients" column, as shown below:

The " $t$ " column shows the calculated t value is 9,684 which is more than critical $t$ value 1.981 . while the "Sig." column is 0.000 which is $<0.05$. These indicates managing resources (MR) influence significantly on innovation performance (IP). Therefore, the second hypothesis $\left(\mathrm{H}_{2}\right)$ is supported by collected data.

The regression equation is:

$$
\text { Innovation Performance }=1,201+0.610 \text { (Managing Resources) }
$$

\section{Discussion}

In this research, the author integrated the literature on entrepreneurial marketing (EM) with that on managing resources and innovation performance. The EM literature identifies proactiveness, opportunity focus, risk taking, customer intensity, innovativeness, resources leveraging and value creation. Becherer, Helms, and McDonald (2012), while the literature on managing resources (Klingebiela and Rammerb, 2011) describe company managing resources to a broader range of innovation projects increases sales of new products. Managing resources cover managing human resources, financial resources, company reputation, business network, physical resources such as building, machineries and raw materials; capabilities and skill. Miller et al. (2015) explain the impact of resources on innovation. Innovation performance 
Table 5. Coefficient of determination for the second sub-model

\begin{tabular}{|l|r|r|r|}
\hline $\mathrm{R}$ & R Square & Adjusted R Square & Std. Error of the Estimate \\
\hline $0.716^{\mathrm{a}}$ & 0.513 & 0.508 & 0.35486 \\
\hline
\end{tabular}

a. Predictors: (Constant), MR

b. Dependent Variable:IP

Table 6. Regression analysis for the second sub-model

\begin{tabular}{|c|c|c|c|c|c|c|}
\hline \multicolumn{2}{|c|}{ Model } & Unstandardized & \multirow{2}{*}{$\begin{array}{c}\text { Coefficients } \\
\text { Std. Error }\end{array}$} & \multirow{2}{*}{$\begin{array}{c}\begin{array}{c}\text { Standardized } \\
\text { Coefficients }\end{array} \\
\text { Beta }\end{array}$} & \multirow{2}{*}{$\mathrm{t}$} & \multirow{2}{*}{ Sig. } \\
\hline & & B & & & & \\
\hline 1 & Constant & 1.201 & 0.199 & & 6.020 & 0.000 \\
\hline & MR & 0.610 & 0.063 & 0.716 & 9.684 & 0.000 \\
\hline
\end{tabular}

a.Dependent Variable: Innovation Performance (IP)

is the process outcome of managing company resources to achieve its competitive advantage. These are tangible, such as new product, product improvement, process improvement, new business model, business model improvement, revenue increase, profitability increase and cost reduction.

Research empirically test the hypothesis on a sample of 91 managers of the companies in Jakarta and part of west Java, Indonesia. The research find that entrepreneurial marketing significantly affect companies in managing their resources. Managing resources also significantly affect innovation performance. These findings are consistent with the research of Hacioglua et al., 2012) that found the positive relationships between the elements of entrepreneurial marketing: proactiveness, innovativeness, customer intensity, resource leveraging dimensions of entrepreneurial marketing, and innovative performance.

\section{Conclusion}

Entrepreneurial marketing significantly affect companies in managing their resources. While managing resources also significantly affect the innovation performance. This research offers an important managerial contribution by concerning entrepreneurial marketing during the managing resources for achieving competitive advantage through innovation performance. It indicates that in managing resources manager must not only proactive, risk taking and innovative, but also the need to create customer value that align on the valuable opportunities.

Therefore, managers accomplish resources for innovation through managing properly human resources, financial resources, company reputation, business network, physical resources such as building, machineries and raw materials; capabilities and skill. Finally, managers who struggle for positioning company to build competitive advantage through innovation must look beyond new product, product improvement, process improvement, revenue increase, profitability increase, cost reduction and consider innovative ways in developing the business model improvement and new business model.

This research is limited to a quantitative empirical evident for the concept of entrepreneurial marketing as only one variable and for unit analysis of managerial levels on manufacture companies in Jakarta, Tanggerang, Bekasi, Karawang, Depok, and Bogor. The author suggests 
that subsequent research to further test the conceptual model and hypothesis of each dimensions of entrepreneurial marketing which are proactiveness, opportunity focus, risk taking, customer intensity, innovativeness, resources leveraging and value creation. The future research should test these conceptual model and hypothesis with larger samples for managerial level on other industry such as service industry and emerging industry such as application and e-commerce industry.

\section{References}

Barney, J.B. (1991). Firm Resources and Sustained Competitive Advantage. Journal of Management, 17(1), pp. 99-120

Becherer, R.C., Haynes, P.J. \& Fletcher L.P. (2006). Paths to profitability in owner-operated firms:The role of entrepreneurial marketing. Journal of Business and Entrepreneurship, 18(1), pp.17-31.

Becherer, R.C., Helms, M.M., \& McDonald, J.P.(2012). The effect of entrepreneurial marketing on outcome goals in SMEs, New England Journal of Entrepreneurship, 15(1).

Bjerke, B. \& Hultman, C.M. (2002). Entrepreneurial marketing: The growth of Small Firms in the New Economic Era, Edward Elgar Publishing Limited, UK

Drucker, P.F. (1985). Innovation and Entrepreneurship.

Gassmann, O., Enkel, E., \& Chesbrough, H. (2010). The future of open innovation. $R \& D$ Management Journal, 40(3), 213-221.

Gronum, S., Verreynne, M.-L., \& Kastelle, T. (2012). The role of networks in small and medium-sized enterprise innovation and firm performance. Journal of Small Business Management, 50(2), 257-282.

Hacioglua G., Erenb S.S., Eren M. S., \& Hale Celikkan H., (2012). The effect of entrepreneurial marketing on firms' innovative performance in Turkish SMEs. Procedia - Social and Behavioral Sciences 58, $871-878$.

Hills, G. E., Hultman, C. M. and Miles, M. P. (2008). The evolution and development of entrepreneurial marketing. Journal of Small Business Management, 46(1), 99-112

Hung, K. P., \& Chou, C. (2013). The impact of open innovation on firm performance: The moderating effects of internal R\&D and environmental turbulence. Technovation, 33, 368-380.

Hunt, S.D. \& Morgan R. M. (1997). Resource-advantage theory: A snake swallowing its tail or a general theory of competition? Journal of Marketing, October Vol. 61, 74-82

Kim, H., \& Park, Y. (2010). The effects of open innovation activity on performance of SMEs: the case of Korea. International. Journal of Technology Management, 52(3-4), 236-256. 
Klingebiela, R. \& Rammerb, C. (2011). Resource allocation flexibility for innovation performance: The fffects of breadth, uncertainty, and selectiveness

Mention, A.L. (2011). Co-operation and co-opetition as open innovation practices in the service sector: Which influence on innovation novelty? Technovation, 31(1), 44-53.

Miller, Wright, and Le Breton-Miller (2015) Resources and innovation in family businesses: The janus-face of family socio-emotional preferences, The California Management Review

Morris, M.H., Schindehutte, M. and LaForge, R.W. (2002), Entrepreneurial marketing: A construct for integrating emerging entrepreneurship and marketing perspectives. Journal of Marketing Theory Practice, 10(4), pp.1-19.

Peteraf, M. A. (1993). The cornerstones of competitive advantage: a resource-based view. Strategic Management Journal, 14(3), pp. 179-191

Rumelt, R. P. (1991). How much does industry matter? Strategic Management Journal, 12 (3), pp. $167-185$

Salter, A., Cricuolo, P., \& Ter Wal, A. (2014). Coping with open innovation. Journal of Innovation Management 3(2), pp. 33-54

Zahra, S. A., \& George, G. (2002). Absorptive capacity: A review, reconceptualization, and extension. Academy of management Review, 27(2), 185-203.

Zahra, S., Filatotchev, I., \& Wright, M. (2009). How do threshold firms sustain corporate entrepreneurship? The role of boards of directors and knowledge. Journal of Business Venturing, 24: 248-260. 